\title{
ACIDIC SOAKING AND STEAM BLANCHING RETAIN ANTHOCYANINS AND POLYPHENOLS IN PURPLE Dioscorea alata FLOUR
}

\author{
[Perendaman Asam dan Blanching Uap Mempertahankan Antosianin \\ dan Polifenol Tepung Dioscorea alata Ungu]
}

\author{
Nelis Imanningsih ${ }^{1)^{*}}$, Deddy Muchtadi2), Tutik Wresdiyati ${ }^{3)}$, Nurheni Sri Palupi ${ }^{2)}$ and Komari ${ }^{1)}$ \\ 1) Pusat Biomedis dan Teknologi Dasar Kesehatan, Badan Litbang Kesehatan, Kementrian Kesehatan Republik Indonesia, Jakarta \\ 2) Departemen IImu dan Teknologi Pangan, Fakultas Teknologi Pertanian, Institut Pertanian Bogor, Bogor \\ 3) Departemen Anatomi, Fisiologi dan Farmakologi, Fakultas Kedokteran Hewan, Institut Pertanian Bogor, Bogor
}

Accepted January 02 2013 / Approved June $03^{\text {th }} 2013$

\begin{abstract}
Purple Dioscorea alata $(D A)$ tuber has health benefits due to its bioactive anthocyanins, which belong to polyphenolic group. Tuber is commonly made into flour to optimize its uses, however, the anthocyanins undergo significant degradation during processing because of the endogenous polyphenol oxidase activities. This research investigated factors that retain anthocyanins and polyphenols in the purple DA flour as well as its antioxidant capacity. The types of treatments during milling process should be taken into account; for instance, soaking in citric acid and blanching in order to preserve the bioactive compounds. To examine the inhibitory effects of acidic soaking and steam blanching on polyphenol oxidase activities, these experiments used four levels of citric acid $(0,0.25,0.5$, and $1 \%)$ and two levels of steam blanching time course (5 and 10 minutes). It was found that steam blanching for 5 or 10 minutes could reduce the activity of polyphenol oxidase, and consequently, retard the oxidation process and retain the polyphenolic compounds. Soaking the purple $D A$ slices into a $1 \%$ citric acid solution followed by steam blanching for $10 \mathrm{~min}$ resulted in the highest total anthocyanins $(104.36 \mathrm{mg} / 100 \mathrm{~g}$ ), polyphenols (198.52 mg equivalent gallic acid/100 g), with an antioxidant capacity of $1.300 \mathrm{mg}$ trolox equivalent/100 g. This study showed that the retention of bioactive compounds of $D A$ tuber through soaking the tuber slices in solution containing inexpensive chemicals like citric acid at low concentrations, combined with 10 minutes of steam blanching resulted in flour containing total anthocyanins and phenolic as high as 44.51 and $62.58 \%$ of fresh tuber, respectively.
\end{abstract}

Keywords: anthocyanins, blanching, citric acid, dioscorea, polyphenols

\begin{abstract}
ABSTRAK
Umbi Dioscorea alata (DA) memiliki manfaat kesehatan karena mengandung senyawa bioaktif antosianin, yang termasuk dalam senyawa polifenol tumbuhan. Saat umbi diolah, komponen bioaktif ini mengalami degradasi yang bermakna karena adanya aktivitas enzim polifenol oksidase. Penelitian ini mempelajari faktor yang dapat mempertahankan kandungan antosianin, polifenol dan kapasitas antioksidan. Untuk mengoptimalkan penggunaannya, umbi diolah menjadi tepung dengan memberi perlakuan perendaman asam sitrat dan blanching untuk mempertahankan komponen bioaktif yang ada di dalamnya. Terdapat empat tingkat perlakuan asam sitrat untuk perendaman $(0 ; 0.25 ; 0.5$, dan 1\%) dan dua tingkat waktu blanching (5 dan 10 menit) yang diuji untuk mengetahui pengaruhnya dalam menghambat aktivitas enzim polifenol oksidase. Dari hasil penelitian ini diketahui bahwa blanching dengan menggunakan uap selama 5 atau 10 menit dapat menurunkan aktivitas enzim polifenol oksidase, sehingga menahan proses oksidasi yang dapat mendegradasi senyawa polifenol. Perlakuan blanching uap selama 10 menit dan perendaman dengan 1\% asam sitrat menghasilkan nilai retensi antosianin tertinggi yaitu $104.36 \mathrm{mg} / 100 \mathrm{~g}$, polifenol sebesar $198.52 \mathrm{mg}$ ekuivalen asam gallat/100 g dan kapasitas antioksidan sebesar $1.300 \mathrm{mg}$ ekuivalen trolox/100 g. Penelitian ini menunjukkan bahwa upaya retensi komponen bioaktif pada umbi DA melalui perendaman pada bahan yang tidak mahal seperti asam sitrat, yang dikombinasikan dengan steam blanching dapat menghasilkan tepung yang memiliki kandungan antosianin dan senyawa polifenol sebesar 44.51 dan $62.58 \%$ dari yang terdapat pada umbi segar.
\end{abstract}

Kata kunci: antosianin, asam sitrat, blanching, dioscorea, polifenol

\section{INTRODUCTION}

Dioscorea alata $(D A)$ tuber, or called greater yam, has been classified as one of the main staple foods in several tropical countries because of high carbohydrate contents. This yam has been proposed to have nutritional superiority compared to other

*Corresponding Author:

Email: n.karyadi@yahoo.com; nelis@litbang.depkes.go.id; Hp: +628121017565 tropical root crops. The tuber contains mainly starch $(75-84 \%$ $\mathrm{dw}$ ) with small amounts of proteins and lipids; and most vitamins and minerals (Chow et al. 2006). Because the colored tuber had antihyperlipidemic, antioxidant and antihypertensive activities; several types of Dioscorea have been used as medicines in oriental countries (Nagai et al. 2006). One of functional compounds of the purple tuber is anthocyanins. Anthocyanins are polyphenolic compounds that have antioxidant capacity through free radicals scavenging mechanisms (Chaovanalikit 
and Wrolstad, 2004). Recent research indicates that anthocyanins have physiological benefits related to the circulating-organ functions e.g. as antioxidant, antiinflammation, blood vessel relaxation, and capillary wall stabilizing agents (Hassellund et al. 2013). Anthocyanins also improve blood lipid profiles by increasing plasma High Density Lipoprotein (HDL) and lowering Low Density Lipoprotein (LDL) (Qin et al. 2009) as well as glutathione peroxidase, an antioxidant enzyme (Xia et al. 2006).

In order to exert health benefits, bioactive compounds of the purple tuber should be preserved during processing. Current knowledge shows several processing factors influence the retention of polyphenolic compounds and its antioxidant capacity. It has been shown that scavenging ability and total phenolic contents decrease with the increase of processing temperature (Hsu et al. 2003). However, short heating reduces the activity of endogenous peroxidase and drying reduces the activity of polyphenol oxidase. These enzymes are responsible for the oxidation of bioactive compounds (Akissoé et al. 2003). The degree of oxidation is assessed using browning index. The lowest browning index of Dioscorea is obtained when the tuber is soaked into citric acid solution (Krishnan et al. 2010).

The uses of Dioscorea tuber in Indonesia is limited. Generally, the tuber is consumed as alternative carbohydrate sources, with a simple processing such as boiling or steaming. This processing only allows consumers to eat the tuber as is Moreover, the loss of bioactive compounds has not been well measured. The uses of the tuber could be extended through Dioscorea flour production. The flour could become ingredients of various food products. An appropriate processing that keeps biologically-active functional compounds of Dioscorea is required to develop functional foods. However, data on bioactive compounds retained during dioscorea flour processing is still scarce. The objective of this research was to study the effects of citric acid soaking and steam blanching on anthocyanin and polyphenol retention as well as the antioxidant capacity of the flour produced.

\section{MATERIALS AND METHODS}

The DA purple tubers were obtained from a farmer in Bogor, Indonesia. The plant species identification was carried out and reconfirmed at Indonesia Institute of Science (LIPI). The tubers were then planted in Bogor (at 6 ${ }^{\circ} 36^{\prime} 0^{\prime \prime} S, 106^{\circ} 48^{\prime} 0^{\prime \prime} \mathrm{E}$ and $265 \mathrm{~m}$ elevation), under humid and rainy climates (in average $70 \% \mathrm{RH}$ and $1.700 \mathrm{~mm}$ precipitation), from June to April. The tubers were harvested at exactly 10 months, therefore, they had relatively homogenous sizes and weights.

\section{Processing $D A$ tuber into flour}

The purple $D A$ tubers were washed, peeled, cut into $5 \mathrm{~cm} \mathrm{x}$ $5 \mathrm{~cm}$ and sliced into $0.5 \mathrm{~cm}$ thickness. The slices were soaked in $0,0.25,0.5$, and $1 \%$ of citric acid (E-Merck) solutions for 30 $\mathrm{min}$, and blanched with steam for 5 and $10 \mathrm{~min}$. The blanced slices were dried at $50^{\circ} \mathrm{C}$ for $24 \mathrm{~h}$, grinded and sieved using a 100 mesh screen. The flour was kept frozen at $-20^{\circ} \mathrm{C}$, and all the analyses were done within a week.

\section{Analysis of proximate}

Proximate analyses (moisture, ash, fat, protein and carbohydrate) were carried out according to AOAC (2007) methods.

\section{Extraction and analysis of total anthocyanin}

Anthocyanins were extracted using methanol (E-Merck) containing $0.1 \%$ hydrochloric acid (E-Merck) (Longo and Vasapollo, 2006). Approximately, $5 \mathrm{~g}$ of powder from each treatment was weighed, then added with $100 \mathrm{~mL}$ methanol containing $0.1 \% \mathrm{HCl}(1: 20$ ratio). The mixture was macerated at $5^{\circ} \mathrm{C}$ overnight. The solution was filtered and the residue was further extracted until colorless/fade purple. The filtrate was mixed and evaporated using a rotary evaporator (Buchi) at $40^{\circ} \mathrm{C}$ to the final volume of $5 \mathrm{~mL}$ extract. The extract was freezestored for 24 hours, and the analysis was performed in the following day.

The total anthocyanins was determined using $\mathrm{pH}$ difference methods (Lee et al. 2005). About $100 \mu \mathrm{L}$ of extract was dissolved in buffer $\mathrm{KCl}-\mathrm{HCl}$ (E-Merck) $\mathrm{pH} 1$ and $\mathrm{pH}$ 4.5. The absorbance was measured at 510 and $700 \mathrm{~nm}$ using UV-Vis spectro-photometer (BioRad). To calculate the total anthocyanin, suitable dilution factors should be foreknown. The sample extract was diluted in the buffer to reach reading absorbances $\leq 1$. The sample extract was dissolved in the buffer solution pH 4.5 and let it settle for 5 min prior to measurements. The absorbance was measured at both wavelength of 510 and $700 \mathrm{~nm}$ in buffer $\mathrm{pH} \mathrm{1;} \mathrm{and} \mathrm{buffer} \mathrm{pH} 4.5$ as blanks. The absorbance value was calculated using the following formula.

$$
\begin{array}{ll}
\mathrm{A}=\left[\left(\mathrm{A}_{510}-\mathrm{A}_{700}\right)_{\mathrm{pH} 1}-\left(\mathrm{A}_{510}-\mathrm{A}_{700}\right)_{\mathrm{pH} 4.5}\right] \\
\mathrm{b} / \mathrm{b}= & \frac{\mathrm{A}}{(\varepsilon \varepsilon \times \mathrm{L})} \times \mathrm{MW} \times \mathrm{DF} \times \frac{\mathrm{V}}{\mathrm{W}_{\mathrm{t}}} \times 100 \% \\
\mathrm{~b} / \mathrm{b} \quad & \text { Anthocyanin content (in \%) } \\
\varepsilon & =\text { Molar coefficient extinction of cyianidin-3-rutinocyde } \\
& =28.800 \mathrm{~L} / \mathrm{cm} \\
\mathrm{L} & =\text { Diameter of cuvette } \\
\mathrm{MW} & =\text { Molecular weight of cyianidin-3-rutinocide } \\
& =445.2 \mathrm{~g} / \text { Mol } \\
\mathrm{DF} & =\text { Dilution factors } \\
\mathrm{V} & =\text { Final volume of extract pigment (L) } \\
\mathrm{W}_{\mathrm{t}} & =\text { Weight of sample }(\mathrm{g})
\end{array}
$$

\section{Total polyphenol analysis}

The total polyphenol analysis of $D A$ flour extract was carried out using a colorimetry method (Chaovanalikit and Wrolstad, 2004). Approximately, $5 \mathrm{~g}$ of powder from each treatment was weighed, and then added with $100 \mathrm{~mL}$ methanol. The mixture was macerated at $5^{\circ} \mathrm{C}$ overnight. The solution was filtered and the residue was further extracted until colorless/fade purple. The filtrate was mixed and evaporated using a rotary evaporator at $40^{\circ} \mathrm{C}$ to the final volume of $5 \mathrm{~mL}$ extract. The extract was freeze-stored for 24 hours, and the analysis was performed in the following day.

Gallic acid (E-Merck) solution was made up through a sequential dilution in deionised water in order to get multi levels of gallic acid standard (Sigma-Aldrich) solutions from 0 to 200 ppm and was used as a standard polyphenol. The standard was 
mixed with a $50 \%$ Folin-Ciocalteu (E-Merck) reagent and $7.5 \mathrm{~mL}$ of deionised water. The mixture was left at room temperature for $10 \mathrm{~min}$ and then added with $1.5 \mathrm{~mL}$ of a $2 \%$ sodium carbonate (E-Merck) solution, heated in a water bath at $40^{\circ} \mathrm{C}$ for $20 \mathrm{~min}$, and quickly cooled. The absorbance of the solution was measured at $755 \mathrm{~nm}$. The absorbances and concentrations of gallic acid were plotted and the linear equation was set. Similarly, the sample was treated as standard was. The absorbances of the sample was put into the equation of the standard, and the concentration of total phenolic was calculated as gallic acid equivallent/100 $\mathrm{g}$ flour.

\section{Analysis of antioxidant capacity}

Antioxidant capacity was analysed using method according to Katsube et al. (2004) by measuring the scavenging of DPPH (1.1- diphenyl-picrylhydrazyl) radicals by sample extract. The DA powder was weighed approximately $5 \mathrm{mg}$, extracted with methanol in a ratio of $1: 20$. The mixture was macerated overnight $(12 \mathrm{~h})$ at $5^{\circ} \mathrm{C}$, filtered, and the residue was extracted for another $60 \mathrm{~min}$ until colorless/fade purple. The filtrates were collected and evaporated using a rotary evaporator at $40^{\circ} \mathrm{C}$ to the final volume of $5 \mathrm{~mL}$. Into the tubes, analytical volumes of $2.8 \mathrm{~mL}$ methanol and $150 \mu \mathrm{L}$ DPPH (Sigma-Aldrich) solution were added. The mixture was left at dark place for $20 \mathrm{~min}$. During the time course, the DPPH radical was scavenged by the antioxidant contained in the samples, so that the colour changed from dark purple to fade-purple colour. The absorbance was measured at $517 \mathrm{~nm}$. Antioxidant capacity was calculated as a difference between DPPH solution and sample absorbance values. Standard curves of trolox (Sigma-Aldrich) was obtained from a serial dilution ranged $250-2.000 \mathrm{ppm}$ in methanol, and were treated similarly to the samples. The linear equation were made by plotting the value of absorbance versus the concentration of standards.

\section{Enzymatic assay of polyphenol oxidase}

Polyphenol oxidase activity was determined using SigmaAldrich (1993) methods. The sampel was prepared by diluting it into water in a ratio of 1:2. There were four reagents made: reagent $A$ was $50 \mathrm{mM}$ buffer potassium phosphate (E-Merck) pH 6.5; B was $5 \mathrm{mM} \mathrm{L-3.4-dihydroxyphenylalanine} \mathrm{solutions} \mathrm{(L-}$ DOPA) (Sigma-Aldrich); C was $2.1 \mathrm{mM} \mathrm{L-ascorbic} \mathrm{acid} \mathrm{(Sigma-}$ Aldrich); and D was 0.065 mM EDTA (E-Merck). To measure the sample, exact volume of $2.6 \mathrm{~mL}$ of reagent $A, 0.1 \mathrm{~mL}$ of reagent $B, C, D$, and $0.1 \mathrm{~mL}$ sample solution was transferred into the cuvette (cylindrical, $1 \mathrm{~cm}$ in diameter). Therefore, there were totally $3 \mathrm{~mL}$ solution in the final reaction mixtures. In another tube a blank was prepared from a mixture of $2.8 \mathrm{~mL}$ of $A, 0.1 \mathrm{~mL}$ of $B$, and $0.1 \mathrm{~mL}$ of $D$. The oxidised L-DOPA produced benzoquinone derivative in the presence of polyphenol oxidase. Afterwards, the benzoquinone was reduced back by L-ascorbic acid, to produce L-DOPA and dehydroascorbic acid. The development of dehydro-ascorbic acid was measured as a difference in absorbance per min (until constant) that was monitored using a thermostat spectrophotometer (BioRad) at $265 \mathrm{~nm}$ at $25^{\circ} \mathrm{C}$. The activity of enzyme was calculated using the following equation.

$$
\text { units enzyme }=\frac{(\mathrm{A} 265 \mathrm{~nm} / \mathrm{min} \text { test })-(\mathrm{A} 265 \mathrm{~nm} / \mathrm{min} \text { blank })}{(0.01)(\mathrm{mg} \text { enzyme } / \text { reaction mix })}
$$

$0.001=$ the change in $\mathrm{A}_{265 \mathrm{~mm}} / \mathrm{min} /$ unit polyphenol oxidase at $\mathrm{pH} 6.5$ at $25^{\circ} \mathrm{C}$ in a $3 \mathrm{~mL}$ reaction mixture

\section{Experimental design}

The design of the experiment was a factorial design run in three replicates. There were four levels of citric acid and two levels of blanching time course. Data was analysed using Analysis of Variant (ANOVA) and Least Significant Different (LSD) test.

\section{RESULTS AND DISCUSSION}

The purple $D A$ tuber had various sizes with diameter ranges of $30-40 \mathrm{~cm}$ and weights approximately of 2-3 kg each (Figure 1). The tuber had a thick and hard skin. The skin took one-third of the tuber total weights. The flesh of the tuber was white with a lot of purple spots scattered. Near the skin, the colour of the flesh was dark purple. Once the flesh cut, the colour rapidly changed into brownish purple indicating polyphenolic oxidation in the presence of endogenous polyphenol oxidase (PPOs) and oxygen. Hence, the flesh should not be exposed to the air for long to avoid the oxidation; therefore, the tubers, for instance, should be soaked immediately after cutting.

The flour making process produced $34.5 \%$ yield. The yield was calculated based on the ratio of the weight of flour to the weight of peeled tuber. The flour produced was purple in colour, however those without citric acid soaking resulted in brownish flours. The flour was immediately packaged in aluminium foil sacks to protect the bioactives from air exposures and lights. The flour was kept in a freezer for 24 hour, and the analysis was performed in the folowing day.

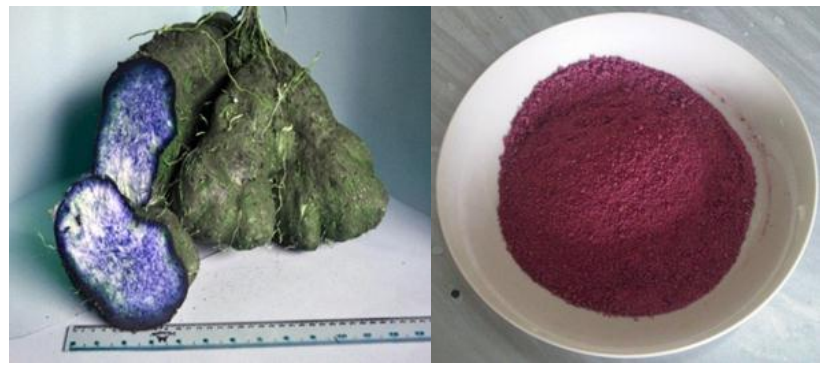

Figure 1. Dioscorea alata tuber and flour obtained from treatment combination of $1 \%$ citric acid soaking and 10 min steam blanching

The raw DA tuber contained $77.16 \%$ (dry basis) of water and $22.86 \%$ dry matter including $8.01 \%$ protein, $3.29 \%$ ash, $1.42 \%$ fat, and $86.96 \%$ carbohydrates. Those data are slightly differed from the findings studied by Behera et al. (2009) i.e. total dry matter of $D A$ is $26.81-33.33 \%$; the protein, fat, ash and carbohydrate contents $7.31-9.67 \%, 0.67-1.30 \%, 1.89-7.08 \%$, and $78.36-82.51 \%$; respectively. The drying process changed composition, namely, a reduction of water content from 70.33 to $8.7 \%$. Consequently, it caused the proportion of dry matters 
such as ash, fat, protein, and carbohydrate increased (Table 1). Citric acid concentration and steam blanching did not cause a significant difference in proximate composition, except for fat content $(p \leq 0.05)$.

Reducing moisture content in purple $D A$ flour could stabilize bioactive compound of the tuber. Water is a critical food component in rendering oxidation of polyphenolic compound because the enzymatic oxidation of phenolic compounds is more intense at a higher moisture content (Stratil et al. 2006). Hence, the drying process should be at a considerably low temperature since a high processing temperature reduces total polyphenols; consequently, decreases the DPPH scavenging activity (Chung et al. 2008).

\section{Total anthocyanins and polyphenols}

Anthocyanins belong to flavonoids, which are widely distributed as plant polyphenol. The flavonoids give red or blue color to flowers, fruits, branches, leafs, and roots. Anthocyanins are water soluble glycosides that consist of polyhydroxy and polymethoxyl derivatives. Total anthocyanins in purple $D A$ tubers in the present study varied among replications. Visually, it was noticed that the purple intensity in $D A$ tuber differed from one to another resulted in a large variance. In the present study the total monomeric anthocyanin pigments of $D A$ tuber were determined using a pH differential method. The total anthocyanin pigments were calculated using cyanidin-3-rutiside coefficients with molar extinction of $28.800 \mathrm{~L} / \mathrm{cm} / \mathrm{Mol}$ and molecular weight of $445.2 / \mathrm{Mol}$. At pH 1, the flavylium cations derived from anthocyanins had red colour whereas at $\mathrm{pH} 4.5$, anthocyanins are generally found in colourless hemiketal forms.

The flour produced through soaking the slices of $D A$ tuber into a $1 \%$ citric acid solution had the highest value of total anthocyanins at all levels of blanching times $(p \leq 0.05)$ (Table 2). Anthocyanins are generally unstable; nevertheless, the stability improves at low $\mathrm{pH}$. A study shows that increasing $\mathrm{pH}$ from 4.3 to 6.0 enhances the degradation of anthocyanins (Kirca et al. 2007). Soaking tuber into citric acid solution was aimed at stabilizing anthocyanins by lowering the $\mathrm{pH}$. The $\mathrm{pH}$ of $0,0.25$, 0.5 and $1 \%$ of citric acid solutions were $6,5.4,4.8$ and 4.3 , respectively. Because the $\mathrm{pH}$ in aqueous environment changes, anthocyanins transform into reversible structures. This transformation causes a change in its color (Chaovanalikit and Wrolstad, 2004). At pH value around 1, the anthocyanins are mainly in the form of flavylium cations whereas at increasing $\mathrm{pH}$ to 4.5 the anthocyanins are predominantly in colourless hemiketal. In neutral aqueous solution, more blue quinonoidal base exists (Lee et al. 2005).

The flavylium cations in acidic $\mathrm{pH}$ are more stable than the colourless hemiketal and quinonoidal base. Soaking the $D A$ into citric acid solution significantly influenced total polyphenol contents. Soaking the tuber in a $1 \%$ citric acid solution gave the highest total polyphenols $(p \leq 0.05)$ in each grup of blanching time course. The effects of acid soaking on the browning index of $D A$ flour has been studied by Krishnan (2010). The browning index is frequently used as a degree of polyphenol oxidation; thus, a lighter colour indicates a lower oxidation degree of polyphenols. Polyphenol oxidase catalyses the oxidation of phenolic compounds to quinones. These further polymerise to brown pigments called melanin. In the present study, the least browning index was found in flour produced from soaking the tubers in citric acid.

Polyphenol oxidase is a $\mathrm{Cu}$ containing enzyme, which catalyzes the oxidation process of 0-diphenol compounds into 0quinones. These quinones are highly reactive and rapidly oxidised, polymerised, and reacted with other quinone molecules, phenolic compounds or with amine groups of proteins. This polimerisation forms a brown pigment called melanin. Polyphenol oxidase activity is influenced by $\mathrm{pH}$, temperature, and the presence of reductive substances (Carbonaro and Mattera, 2001). The present study found the use of $1 \%$ citric acid solution lowered the $\mathrm{pH}$ of the $D A$ tuber flesh to 4.3. At lower pHs, the action of PPOs was retarded. The $\mathrm{pH}$ activity for PPOs depends on the genetic properties of the plant and the nature of polyphenolic substrates. For example, crude PPOs from taro has a maximum activity at around $\mathrm{pH}$ 4.6, while from potato at around $\mathrm{pH} 6.8$ with a narrow plateau between $\mathrm{pH} 4.4$ and 6.0. Any endogenous PPOs are nearly inactive at pH 4.0 (Duangmal and Apenten, 1999).

Table 1. Proximate composition of fresh purple DA tuber and flour

\begin{tabular}{|c|c|c|c|c|c|c|}
\hline \multicolumn{2}{|c|}{ Treatments } & \multirow{2}{*}{$\begin{array}{c}\text { Moisture } \\
\quad(\%) \\
\text { Dry Basis }\end{array}$} & \multirow{2}{*}{$\begin{array}{c}\text { Ash } \\
(\%) \\
\text { Dry Basis }\end{array}$} & \multirow{2}{*}{$\begin{array}{c}\text { Fat } \\
(\%) \\
\text { Dry Basis }\end{array}$} & \multirow{2}{*}{$\begin{array}{c}\text { Protein } \\
(\%) \\
\text { Dry Basis }\end{array}$} & \multirow{2}{*}{$\begin{array}{c}\text { Carbohydrate } \\
(\%)\end{array}$} \\
\hline $\begin{array}{l}\text { Blanching Duration } \\
\text { (min) }\end{array}$ & $\begin{array}{c}\text { Citric Acid } \\
\text { Concentration (\%) }\end{array}$ & & & & & \\
\hline Fres tuber & & $77.16 \pm 7.75$ & $3.29 \pm 1.64$ & $1.42 \pm 0.46$ & $8.01 \pm 1.30$ & $86.95 \pm 2.69$ \\
\hline \multicolumn{7}{|l|}{ Flour } \\
\hline 5 & 0.00 & $8.67 \pm 1.05$ & $2.78 \pm 1.00$ & $0.67 \pm 0.12^{b}$ & $7.98 \pm 1.88$ & $88.57 \pm 2.39$ \\
\hline 5 & 0.25 & $8.63 \pm 0.95$ & $2.84 \pm 0.95$ & $0.63 \pm 0.12^{b}$ & $8.29 \pm 1.44$ & $88.24 \pm 1.97$ \\
\hline 5 & 0.50 & $8.36 \pm 0.46$ & $2.67 \pm 1.02$ & $0.67 \pm 0.14^{b}$ & $7.71 \pm 1.47$ & $88.95 \pm 2.19$ \\
\hline 5 & 1.00 & $8.70 \pm 0.36$ & $2.54 \pm 0.95$ & $0.66 \pm 0.12^{b}$ & $7.57 \pm 1.42$ & $89.23 \pm 2.07$ \\
\hline 10 & 0.00 & $8.48 \pm 0.46$ & $3.04 \pm 0.49$ & $1.00 \pm 0.16^{a}$ & $8.08 \pm 0.60$ & $87.88 \pm 0.56$ \\
\hline 10 & 0.25 & $8.54 \pm 0.50$ & $2.79 \pm 0.60$ & $1.02 \pm 0.13^{a}$ & $8.37 \pm 0.09$ & $87.82 \pm 0.69$ \\
\hline 10 & 0.50 & $9.05 \pm 0.76$ & $2.86 \pm 0.52$ & $1.14 \pm 0.16^{a}$ & $8.71 \pm 0.66$ & $87.29 \pm 1.10$ \\
\hline 10 & 1.00 & $8.55 \pm 0.33$ & $2.62 \pm 0.76$ & $0.97 \pm 0.14^{a}$ & $8.55 \pm 0.75$ & $87.86 \pm 1.06$ \\
\hline
\end{tabular}

*The value followed by different letter in the same column, indicated a significant difference $(p \leq 0.05)$ 
Table 2. The differences in total anthocyanins, total polyphenol and antioxidant capacity of purple DA flour treated with citric acid soaking at various concentrations and steam blanching for 5 and 10 minutes

\begin{tabular}{|c|c|c|c|c|}
\hline \multicolumn{2}{|c|}{ Treatments } & \multirow{2}{*}{$\begin{array}{c}\text { Total Anthocyanins }(\mathrm{mg} / 100 \mathrm{~g}) \\
\text { Dry Basis } \\
\text { mean } \pm \text { SD }\end{array}$} & \multirow{2}{*}{$\begin{array}{c}\text { Total Polyphenol } \\
\text { (mg EGA/100 g) Dry Basis } \\
\text { mean } \pm \text { SD }\end{array}$} & \multirow{2}{*}{$\begin{array}{c}\text { Antioxidant Capacity } \\
\text { (mg ETX/100 g) } \\
\text { mean } \pm \text { SD }\end{array}$} \\
\hline $\begin{array}{l}\text { Duration Steam Blanching } \\
(\mathrm{min})\end{array}$ & $\begin{array}{c}\text { Citric Acid Concentration } \\
(\%)\end{array}$ & & & \\
\hline 5 & 0.00 & $36.09 \pm 5.90 \mathrm{e}$ & $85.36 \pm 8.65^{d}$ & $536 \pm 172.25^{c}$ \\
\hline 5 & 0.25 & $40.85 \pm 12.49 \mathrm{de}$ & $142.53 \pm 11.36^{c}$ & $585 \pm 298.42^{c}$ \\
\hline 5 & 0.50 & $53.28 \pm 8.31^{\mathrm{cd}}$ & $159.91 \pm 15.75^{b}$ & $666 \pm 199.58 \mathrm{c}$ \\
\hline 5 & 1.00 & $63.76 \pm 12.30 c$ & $190.65 \pm 1.00^{a}$ & $752 \pm 237.96 b^{c}$ \\
\hline 10 & 0.00 & $57.28 \pm 3.40^{c}$ & $167.22 \pm 11.83^{b}$ & $1016 \pm 280.97$ ab \\
\hline 10 & 0.25 & $62.24 \pm 6.22^{c}$ & $166.70 \pm 5.89^{b}$ & $1229 \pm 50.82^{\mathrm{a}}$ \\
\hline 10 & 0.50 & $82.34 \pm 1.39 b$ & $163.70 \pm 2.30^{\mathrm{b}}$ & $1269 \pm 27.62^{\mathrm{a}}$ \\
\hline 10 & 1.00 & $104.36 \pm 13.98^{a}$ & $198.52 \pm 10.38^{a}$ & $1300 \pm 17.04^{a}$ \\
\hline
\end{tabular}

*Value followed by a different letter in the same column indicated a significant different between

treatments ( $p \leq 0.05) ; E G A=$ Equivallent Gallic Acid; ETX = Equivallent Trolox

The time course of blanching also affected total anthocyanins and polyphenols. The results of blanching for 10 minutes exhibited a higher anthocyanin and polyphenolic contents compared to that of 5 minutes at all levels of citric acid $(p \leq 0.05)$. The steam blanching process was aimed at inactivating PPOs which acted as catalist in oxidation of anthocyanins and polyphenols. PPO is an effective catalist that reduce the activation energy of oxidation reaction. The steam blanching methods have already been used for stabilizing anthocyanins in cherries. The blanched cherries retain more anthocyanins than unblanched cherries. It is likely that PPOs have been inactivated completely since polyphenol oxidase cause anthocyanin degradation (Lee et al. 2002).

Total anthocyanins and polyphenols in the presence of polyphenol oxidase cause high oxidation which is concomitant with the reduction of polyphenols and subsequently the activity of polyphenol oxidase. Data of enzymic assays indicated that fresh purple $D A$ tuber exhibited a high activity of polyphenol oxidase. After the tuber was blanched for 5 minutes, the enzymatic activity decreased sharply to less than $10 \%$ of the initial value (Figure 2). The reduction after 10 minutes blanching could be more; although the value did not differ from that of 5 minutes blanching (LSD All-Pair wise Comparisons Test). Apparently, the steam heating vigorously deteriorated polyphenol activity. The heat denatured enzyme and changed its tertiary structure that abolished the active site (Duangma and Apenten, 1999). Soaking DA tuber in citric acid solution also reduced the activity of polyphenol oxidase. At the level of citric acid of $0.25 \%$ the activity decreased to half of the initial values, but at $1 \%$ of citric acid, the activity decreased to only $10 \%$ of initial activity. The citric acid lowered the $\mathrm{pH}$ of purple $D A$ flesh to 4.3. Meanwhile, the optimum $\mathrm{pH}$ for PPO activities is between 6.0-6.5. Therefore, the activity of PPOs is likely to be retarded at lower $\mathrm{pH}$ in agreement with findings of Carbonaro and Mattera (2001).

The fresh purple tuber of DA contained $234.46 \mathrm{mg} / 100 \mathrm{~g}$ of antocynins and $317.73 \mathrm{mg}$ equivalent gallic acid of polyphenols (dry based). The interaction between 1\% of citric acid solution and 10 minutes steam blanching resulted in the highest anthocyanin and polyphenolic compounds that were 104.36 $\mathrm{mg} / 100 \mathrm{~g}$ and $198.52 \mathrm{mg}$ equivalent gallic acid/100 $\mathrm{g}$ flour (dry based), respectively. Apparently, the lowering $\mathrm{pH}$ effects of citric acid soaking combined with appropriate heating during steam blanching retained anthocyanins and polyphenol as high as 44.51 and $62.58 \%$ of initial values.
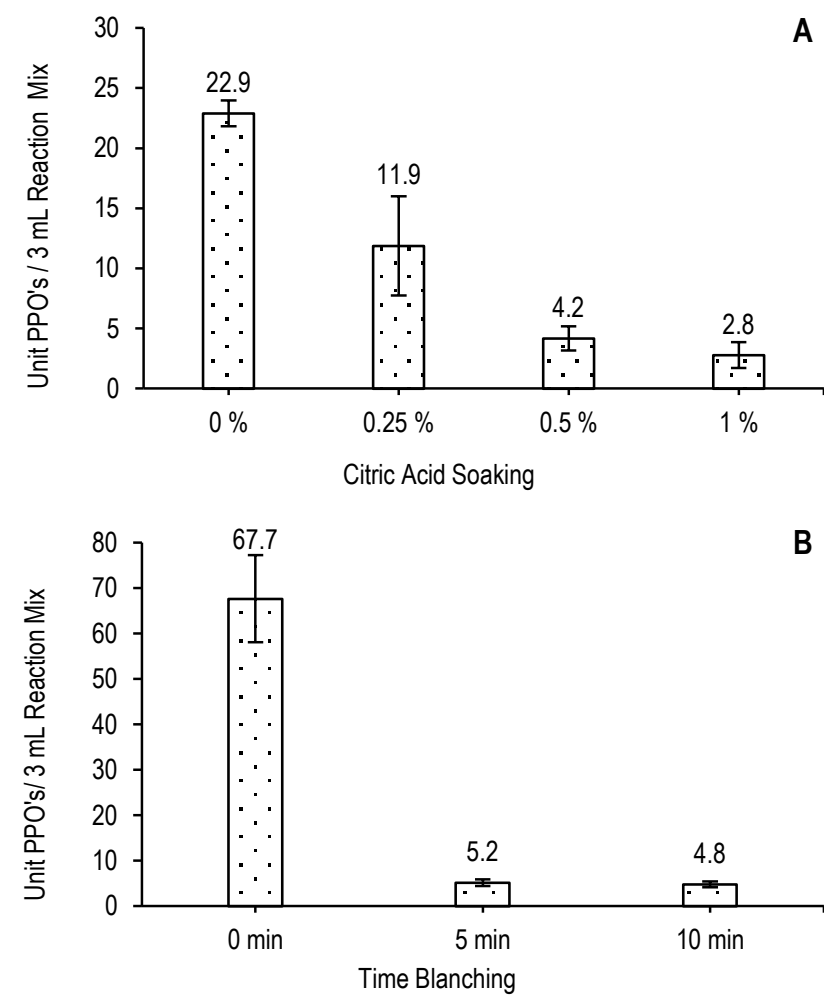

Figure 2. The reduction of polyphenol oxidase activity due to citric acid soaking at various concentrations $(A)$ and steam blanching for 5 and 10 minutes (B)

\section{Antioxidant capacity}

The antioxidant capacity is expressed as $\mathrm{mg}$ trolox equivalent. The value of trolox standard curve was obtained by plotting the multi levels of trolox (X-axis) from 250 to $2.000 \mathrm{ppm}$ versus the antioxidant capacity that is the difference of absorbances between 1.1-diphenyl-2- picrylhydrazyl (DPPH) free radical solution and the multi solution of trolox at $517 \mathrm{~nm}$ (Y-axis). A correlation between the two variables was used to 
develop a prediction equation. The regression equation of standard curve of trolox obtained in this research had $r^{2}$ value of 0.9947. Right after the DPPH radicals reacted with sample, the free radical was scavenged by polyphenol compounds of the samples. Initially, the colour of solution was dark purple. After reaction, the colour changed from dark purple to a lighter purple or colourless as a sign of scavenging activity. The lighter the color of solution, the lower the absorbance; this indicates a better DPPH scavenging ability (Chen et al. 2008).

The blanching time course and citric acid concentration had significant influences on the antioxidant capacity $(p \leq 0.95)$. Amongst treatments, the flour produced from soaking into a $1 \%$ citric acid solution and 10 minutes blanching had the highest value of antioxidant capacity (LSD All-Pair wise Comparisons Test). The highest antioxidant capacity of $100 \mathrm{~g}$ flour was equivalent to $1.300 \mathrm{mg}$ trolox. The antioxidant capacity of $D A$ extracts related to the total anthocyanins and polyphenols. A higher content of anthocyanins and polyphenolic substances resulted in a higher antioxidant capacity (Table 2, Figure 3). Polyphenols have been known highly correlating with and as the main contributor to antioxidant capacity (Du et al. 2009). There was correlation between the level of polyphenol, anthocyanins and antioxidant capacity. Pearson correlation analysis showed that the correlation between the level of anthocyanin and antioxidant capacity (0.6993) was higher than those of polyphenol and antioxidant capacity (0.5419).

Nevertheless, the steam blanching was more determinant than acid soaking for antioxidant capacity. The steam blanching for 10 minutes produced a significant difference in antioxidant capacity than that of 5 minutes. Although a 1\% citric acid solution had the highest mean value of antioxidant capacity compared to other concentrations, this value did not differ significantly from those of $0.25 \%$ and $0.5 \%$. Blanching is one of the most important preparation steps in processing of fresh vegetables. The primary purposes of blanching is to inactivate enzymes involving in oxidation of polyphenolic compounds. Several studies report that blanching either increases or decreases antioxidant capacity through different mechanisms. On the other hand, dip blanching tends to reduce the antioxidant capacity since the phenolic compounds are dissolved into the blanching water. The extent of reductions depend on time course and temperature applied (Amin et al. 2006). Steam blanching, however, had been reported to increase anthocyanins and phenols, as a result, the antioxidant capacity also incerase. This is because the steam succesfully inactivates the PPOs (Rossi et al. 2003). Simultaneously, the steam blanching method enables the bioactives stay intact in the product, not leaching out. Moreover, a study carried out by Chung et al. (2008) shows that $\mathrm{pH}$ influences the radical scavenging ability. The DA extract treated with low $\mathrm{pHs}(\mathrm{pH} 4$ 5) has a better radical scavenging ability i.e. it is comparable to Butillated Hidroxy Annisole (BHA) and vitamin E. There was a negative relationship between $\mathrm{pH}$ and scavenging ability. When the $\mathrm{pH}$ was elevated, the radical scavenging ability decreased.

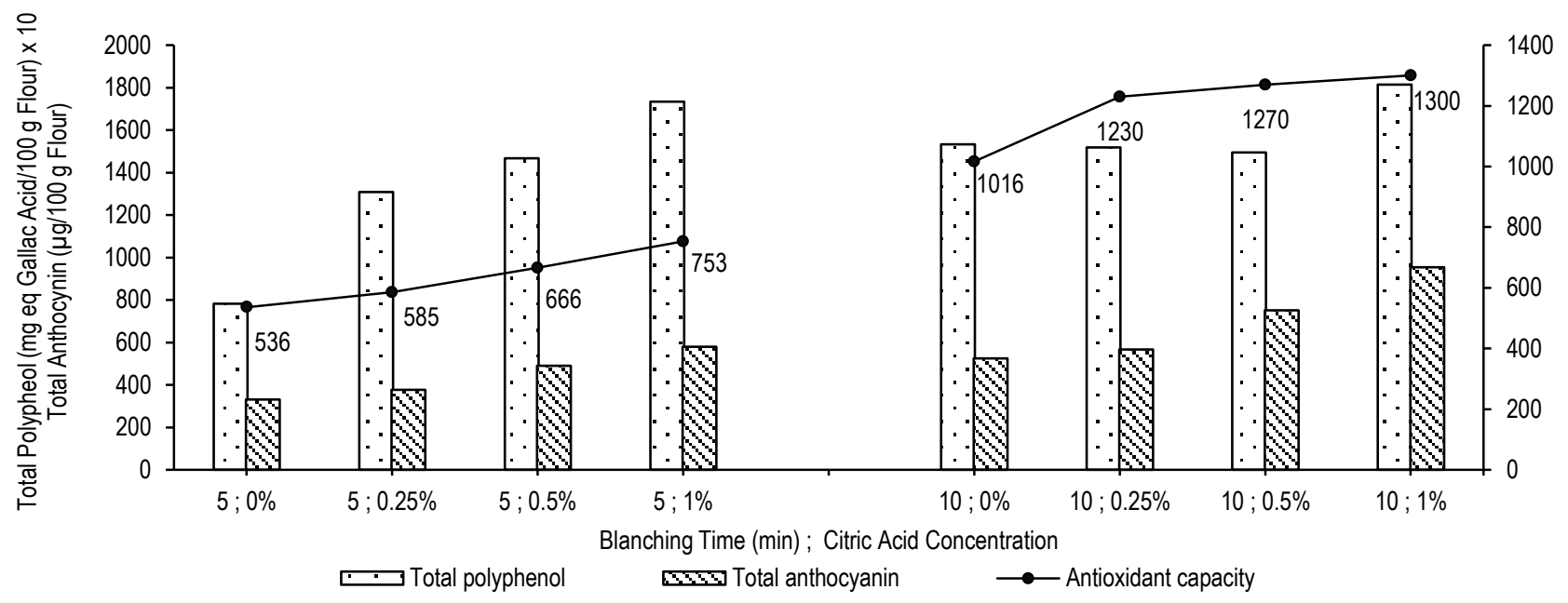

Figure 3. Total polyphenols, anthocyanins and antioxidant capacity of purple $D A$ flour 


\section{CONCLUSION}

Anthocyanin and polyphenolic contents in purple $D A$ flour could be retained through citric acid soaking and steam blanching treatments. The study showed that the retention of bioactive compounds could be carried out by soaking the slices of purple $D A$ tuber in a $1 \%$ citric acid solution and blanching them in a steam heating process for $10 \mathrm{~min}$. The treated slices yielded flour in which $44.51 \%$ of anthocyanin and $62.58 \%$ of polyphenolics could be retained. The flour had a strong antioxidant capacity equal to $1.300 \mathrm{mg}$ trolox. Further study is needed to investigate the type of anthocyanins retained due to these treatments.

\section{ACKNOWLEDGEMENT}

This research was funded by the National Institute of Health Research and Development Center Ministry of Health of Indonesia through Acceleration of Indonesia Doctorate Program (PADI).

\section{REFERENCES}

Akissoé N, Hounhouigan J, Mestres C, Nago M. 2003. How blanching and drying affect the colour and functional characteristics of yam (Dioscorea cayenensis-rotundata) flour. Food Chem 82: 257-264. DOI: 10.1016/S03088146(02)00546-0.

Amin I, Norazaidah Y, Hainida EKI. 2006. Antioxidant activity and phenolic content of raw and blanched Amaranthus species. Food Chem 94: 47-52. DOI: 10.1016/j.foodchem. 2004.10.048.

[AOAC] Association of Official Agricultural Chemists. 2007. Official Methods of Analysis of AOAC International 18th ed. AOAC International, Maryland.

Behera KK, Maharana T, Sahoo S, Prusti A. 2009. Biochemical quantification of protein, fat, starch, crude fiber, ash and dry matter content in different collection of greater yam (Dioscorea alata L) found in Orissa. Nature Sci 7: 24-32.

Carbonaro M, Mattera M. 2001. Poliphenol activity and polyphenol levels in organically and conventionally grown peach (Prunus persica L., cv. Regina bianca) and pear (Pyrus communis L., cv. Williams). Food Chem 72: 419-424. DOI: 10.1016/S0308-8146(00)00248-X.

Chaovanalikit A, Wrolstad RE. 2004. Total anthocyanins and total phenolics of fresh and processed cherries and their antioxidant properties. J Food Sci 69: FCT67-FCT72. DOI: 10.1111/j.1365-2621.2004.tb17858.x.

Chen YT, Kao WT, Lin KW. 2008. Effects of pH on the total phenolic compound, antioxidative ability and the stability of dioscorin of various yam cultivars. Food Chem 107: 250257. DOI: $10.1016 /$ j.foodchem.2007.08.017.
Chow ST, Chiang BH, Chung YC, Chen PC, Hsu CK. 2006. Effects of storage temperatures on the antioxidative activity and composition of yam. Food Chem 98: 618-623. DOI: 10.1016/j.foodchem.2005.06.039.

Chung YC, Chiang BH, Wei JH, Wang CK, Chen PC, Hsu CK. 2008. Effects of blanching, drying and extraction processes on the antioxidant activity of yam (Dioscorea alata). Int $\mathrm{J}$ Food Sci Tech 43: 859-864. DOI: 10.1111/j.1365-2621. 2007.01528.x.

Du G, Li M, Ma F. 2009. Antioxidant capacity and the relationship with polyphenol and vitamin $\mathrm{C}$ in Actinidia fruits. Food Chem 113: 557-562. DOI: 10.1016/j.foodchem. 2008. 08.025 .

Duangmal K, Apenten RKO. 1999. A comparative study of polyphenol oxidases from taro (Colocasia esculenta) and potato (Solanum tuberosum var Romano). Food Chem 64: 351-359. DOI: 10.1016/S0308-8146(98)00127-7.

Hassellund SS, Flaa A, Kjedsen SE, Seljeflot I, Karlsen A, Erlund I, Rostrup M. 2013. The effects of anthocyanins on cardiovascular risk factors and inflammation in prehypertensive men: a double-blind randomized placebocontrolled crossover study. J Hum Hypertens 27: 100-106. DOI: 10.1038/jhh.2012.4.

Hsu CL, Chen W, Weng YM, Tseng CY. 2003. Chemical composition, physical properties, and antioxidant activities of yam flours as affected by different drying methods. Food Chem 83: 85-92. DOI: 10.1016/S0308-8146(03)00053-0.

Katsube T, Tabata H, Ohta Y, Yamasaki Y, Anuurad E, Shiwaku $\mathrm{K}$, Yamane Y. 2004. Screening for antioxidant activity in edible plant products: comparison of low-density lipoprotein oxidation assay, DPPH radical scavenging assay and FolinCiocalteu assay. J Agr Food Chem 52: 2391-2396. DOI: $10.1021 / \mathrm{jf0} 35372 \mathrm{~g}$.

Kirca A, Ozkan M, Cemerogu B. 2007. Effects of temperature, solid content and $\mathrm{pH}$ on the stability of black carrot anthocyanins. Food Chem 101: 212-218. DOI: 10.1016/j. foodchem.2006.01.019.

Krishnan JG, Padmaja G, Moorthy SN, Suja G, Sajeev MS. 2010. Effect of pre-soaking treatments on the nutritional profile and browning index of sweet potato and yam flours. Innov Food Sci Emerg 11: 387-393. DOI: 10.1016/j. ifset.2010.01.010.

Lee J, Durst RW, Wrolstad RE. 2002. Impact of juice processing on blueberry anthocyanins and polyphenolics: comparison of two pretreatments. J Food Sci 67: 1660-1667. DOI: 10.1111/j.1365-2621.2002.tb08701.x.

Lee J, Durst RW, Wrolstad RE. 2005. Determination of total monomeric anthocyanin pigment content of fruit juice, beverages, natural colorants and wines by the $\mathrm{pH}$ differential methods: collaborative study. J AOAC Int 88: 1269-1278. 
Longo L, Vasapollo G. 2006. Extraction and identification of anthocyanins from Smilax aspera $L$. berries. Food Chem 94: 226-231. DOI: 10.1016/j.foodchem.2004.11.008.

Nagai T, Suzuki N, Nagashima T. 2006. Antioxidative activity of water extracts from the yam (Dioscorea opposita Thunb.) tuber mucilage tororo. Eur J Lipid Sci Tech 108: 526-531. DOI: 10.1002/ejtt.200500231.

Qin Y, Xia M, Ma, J, Hao YT, Liu J, Mou HY, Cao L, Ling WH. 2009. Anthocyanin supplementation improves serum LDLand HDL-cholesterol concentrations associated with the inhibition of cholesteryl ester transfer protein in dyslipidemic subjects 1,2,3,4. Am J Clin Nutr 90: 485-492. DOI: 10.3945/ ajcn.2009.27814.

Rossi M, Giussani E, Morelli R, Scalzo RL, Nani RC, Torreggiani D. 2003. Effect of fruit blanching on phenolics and radical scavenging activity of highbush blueberry juice. Food Res Int 36: 999-1005. DOI: 10.1016/j.foodres.2003. 07.002.

Sigma-Aldrich. 1993. Enzymatic assay of polyphenol oxidase. Http://www.sigmaaldrich.com/etc/medialib/docs/.../polyphen ol_oxidase.pdf [July 07th 2012].

Stratil P, Klejdus B, Kuban V. 2006. Determination of total content of phenolic compound and their antioxidant activity in vegetables-evaluation of spectrophotometric methods. J Agr Food Chem 54: 607-616. DOI: 10.1021/jjjf052334j.

Xia X, Ling W, Ma J, Xia M, Hou M, Wang Q, Zhu H, Tang Z. 2006. An anthocyanin-rich extract from black rice enhances atherosclerotic plaque stabilization in apolipoprotein edeficient mice. J Nutr 136: 2220-2225. 